Article

\title{
Pricing Industrial Discharge Quota (IDQ): A Model Reflecting Opportunity Cost of Performing Ecological Responsibility
}

\author{
Tengda Lu ${ }^{1}\left(\mathbb{D}\right.$, Xieer Dai $^{2}$, Jun Chen ${ }^{1}$ (D) and Ming Dai ${ }^{1, *}$ \\ 1 College of Economics, Jinan University, Guangzhou 510632, China; lutengda@stu2016.jnu.edu.cn (T.L.); \\ chenjun@stu2016.jnu.edu.cn (J.C.) \\ 2 Department of Economics, Hebrew University, Jerusalem 97665, Israel; daixieer@gmail.com \\ * Correspondence: tdaiming@jnu.edu.cn; Tel.: +86-20-8522-0187; Fax: +86-20-8522-0187
}

Received: 5 May 2018; Accepted: 8 June 2018; Published: 15 June 2018

\begin{abstract}
The upper reaches of a river system are often trapped in the dilemma of choosing between industrial development and headwater protection. One of the solutions is eco-compensation, which, however, is a public-fiscal arrangement lacking inspiration and sustainability. Instead, industrial discharge quota (IDQ) was put forward as a marketized approach: the maximum industrial discharge a river can afford is allocated as quotas and quotas are allowed to be traded. However, what pricing principle in the primary market can IDQ price refer to? How can enough incentives be given to local governments when they are reluctant to implement emission reduction policy? Given that some previous studies have proven the influence of fiscal income and reputation on governments' incentives, this paper introduces these into our model as main factors. Through analysis, two models—government model and enterprise model—are formulated based on opportunity cost theory to deal with this problem. The first sets basic prices and the latter notifies enterprises' behaviors. Then, this paper applies our first model to a sample region, Fogang County in Pearl River Basin. The results demonstrate that the upstream can obtain adequate compensation for their opportunity loss and local governments can be with strong motivation by our method.
\end{abstract}

Keywords: ecological responsibility; marketized solution; industrial discharge quota (IDQ); opportunity cost; watershed area (river basin); governments' motivation

\section{Introduction}

Conflicts between economic development and environmental protection have already become one of the most serious threats to regional balanced development in China. Usually, due to different resource endowments and different market environments, areas bearing more environmental responsibility establish factories under strict limitation while those with less responsibility get more opportunities to develop various industries. When it comes to watersheds, this problem stands out most because the upstream is so sensitive to sewage discharge and the downstream is blessed with many economic advantages thanks to its location [1].

In China, water pollution as a by-product of rapid economic development and industrialization has been a pressing social issue for many decades [2-4]. Since 1978, when the policy of reform and opening up was adopted, Chinese governments attached the utmost importance on the high speed of economic development but little on environmental protection, intensifying water scarcity and worsening water quality. Firstly, it can be reflected by the scale of pollution. According to China Statistical Yearbook on Environment, the official data have shown a steady growth in the total amount of waste water per year, from 65,919 million tons in 2011 to 76,500 million tons in 2016. Concretely, citing 
the eastern coastal areas as an example, the amount of wastewater has boomed from 22,800 million tons in 2003 to 33,100 million tons in 2010, whose proportion of the total industrial discharge increased dramatically from $50.1 \%$ (2003) to $60.8 \%$ (2010) [5]. Secondly, it can be reflected by pollution degree. Water quality has not been improved noticeably. The percentages of $\mathrm{V}$ type water, which cannot be used for daily life, in the Haihe River, Huaihe River, Yellow River and Liaohe River were as much as $41.0 \%, 15.6 \%, 6.6 \%$ and $22.6 \%$, respectively, in 2016. However, World Water Assessments Programme made a prediction about water demand tendency from 2005 to 2030, claiming that business-as-usual demand would exceed the reserves of bulk water and that China's water demand would grow to 818 billion $\mathrm{m}^{3}$ in 2030, at a compound annual growth rate (CAGR) of $1.6 \%$ [6]. Thus, it is necessary to find a good solution to water protection.

Governments have realized this problem and considered this issue recently. Although some changes have been made [7], current policies still cannot get rid of this dilemma entirely [8]. One of the measures is named Major Functional Areas Planning, which is based on the principles of comparative advantages. In this policy, the whole region is segmented into four areas: optimal area, key area, limited area and prohibited area [9]. As a result, owing to the higher ecological cost in the upstream than in the downstream, central government are apt to concentrate on the downstream, which is actually at the expense of the development of the upstream. Another measure to lessen the acute contradiction is Watershed Payment for Ecological Service (W-PES) [10-12], which aims to fix the shortcomings of Major Functional Areas Planning by compensating the upstream in government means. Countries such as America [13] and Germany [14] have made some achievements in Catskills and Elbe, respectively (two important watershed in the two countries), with this approach. However, it is also with limitation in China for it depends much on government's management and barely takes advantage of market power [15-17]. Besides, practices have already proven that resource distribution dominated by governments is not a good idea, due to not only low efficiency but also corruption.

Against this backdrop, scholars referred to carbon trading and proposed industrial discharge quota (IDQ) as the solution. As an emission reduction measure, this mechanism sets a limit on the emission amount and allows IDQ owners to discharge only within quotas they own. As a marketized measure, this mechanism permits owners to trade with others in the secondary market. In this way, the visible hand and invisible hand are combined so that emission reduction task can be assigned by market behavior and financial losses of local governments can be compensated. Nevertheless, how to set a proper price for IDQ initial allocation to give incentives to governments and how enterprises' decisions affect governments are still far from resolved. Especially, local government incentives are really the crucial key to successful implementation. Thus, considering the opportunity loss of governments and enterprises' goals to maximize profits, this paper mainly focuses on the following questions:

(1) How can a model based on opportunity cost theory be built? In practice, which of the factors are governments concerned about?

(2) To achieve more production, what strategies can enterprises select? How do they affect government's policy?

(3) How can this model be implemented in practice?

The remainder of this paper is designed as follows. In Section 2, we make a brief and focused review of related studies. Section 3 establishes our pricing model based on opportunity cost theory. Section 4 introduces our study area and data. In Section 5, a case study to test our government model is presented. Section 6 proves the necessity of IDQ policy. We show our conclusions in Section 7.

\section{Literature Review}

Studies have been pumped into environmental-friendly economy and sustainable development so far, creating much related literature. Here, this paper focuses on four subjects: sustainability, 
payment for ecosystem services (PES), the distribution method in primary market and some price research related to IDQ.

Sustainability emerged around in the 1970s with the awareness that environment had been destroyed seriously after two world wars and during the process of industrialization. It was not until 1987 that its classical implication was put forward officially for the first time by the World Commission on Development and Environment (WCDE) and defined as satisfying the demands of current people without depriving of the rights of future generations. Then, starting with the Union Nations (UN) Conference on Environment and Development [18], global societies formulated many sustainable development policies and agendas [19], such as China's Agenda 21. However, in the meantime, inter-regional inequity, some of which was due to unequal ecological responsibility, had also become a big issue. Thus, scholars combined environment problems (inter-general equity) with economic problems (inter-regional equity). Shaker and Sirodoev [20] concluded that sustainable development should cover three key systems, environment, economy and society, which means sustainable development demands us to take inter-regional equity into account [21] rather than inter-general equity only. The United Nations released and ratified Sustainable Development Goals (SDGs) in 2015, which contained 17 aspects and associated closely with economic development [22]. In brief, sustainability merely emphasizing on inter-generation justice or environment protection is inadvisable and inappropriate, and it is necessary to be associated with inter-regional justice and balanced development.

Payment for ecosystem service (PES) and emission trading are two ways to get out of this dilemma. PES was a relatively mature measure [23] and its definition was "voluntary transactions between ecosystem service (ES) users and ES providers that are conditional on agreed rules of natural resource management for generating offsite services" [24]. Gabriela and Jeff [25] confirmed that PES had the potential to mimic competitive markets only if conditions in Coase theorem [26] were satisfied. In practice, there emerged some crosscurrents because PES lacked market attributes-placing much weight on voluntary property [27], refusing to use concepts of "seller" and "buyer" and not recognizing the existence of PES market [28]. Hence, it turned out to be more like government actions rather than market behaviors [15-17,29]. Instead, emission trading is a market-based policy. It was first used for water pollution research in 1968 by Dales [30] and for air pollution research in 1966 by Croker [31]. Montgomery [32] proved that emission trading is more efficient to deal with the dilemma than traditional measures, as it minimized the coordination cost by reallocating the reduction amount through market transaction. Further research by Bohm [33] and Fisher-vanden [34] pointed out the total cost of environmental protection was kept at minimum through tradable quota. As for practice, America was the first country putting it into practice for managing air pollution with the $\mathrm{SO}_{2}$ allowance-trading program to address the threat of acid rain in the Clean Air Act Amendments of 1990 [35]. Besides, carbon emission has set up systematic framework [36] and three well-run mechanisms, namely IET, CDM and JI. Up until now, it has been with a large market volume and fruitful results, especially for the European market and EU-ETS [37,38]. In China, Zhou et al. measured and proved that the cost of carbon emission reduction declined by $40 \%$ with quota trading [39].

Initial distribution in the primary market is critical to IDQ [40]. Hahn [41] pointed out that different initial distributions of quotas have different impacts on the efficiency of transaction in an imperfectly competitive market. Fan et al. proved the positive relation between the intensity of abatement and macro-economic costs of per unit emission reduction [42]. Currently, most governments in primary market take the free allocation mechanism as the principle, which, however, may cause the problems of inequity, lobbying, etc. [43]. Studying on the distribution of carbon emission permits, Pizer [44] compared many factors of free allocation and auction, such as incomes for participants, dynamic efficiency, cost distribution effect, etc., and concluded that free allocation could reduce resistances from enterprises at initial stage but auctions have comparative advantage overall. In addition, through the research on carbon emission rights, Betz et al. [45] found that an effective auction mechanism could really prompt the market behavior of companies by price signals and could reduce capital losses 
compared with other distribution mechanisms. As a result, to set a reasonable basic price is the next significant step for IDQ.

Besides, price studies related to IDQ are also rich but most them only focus on the price in the secondary market. Firstly, influential factors of price in the secondary is one of the hottest fields. For example, Christiansen [46] and Mansanet-Bataller [47] discussed the influential factors of carbon price, which included climate, weather, the price of energy, social productivity, etc. Bredin and Muckley [48] proved the strong correlation between carbon price and stock market. Secondly, study of emission pricing is in a similar situation, concentrating on secondary market mainly. The shadow price model is the common model used in resource pricing in the secondary market and has been prove $\mathrm{n}$ to be effective in measuring the equilibrium price $[49,50]$. In addition to shadow price model, Jan Seifert et al. [51] established stochastic equilibrium model to predict the dynamic change of carbon price in secondary market but this approach needed a great amount of daily data and is complicated in practice. Moreover, there are replacement cost model [52], model of consultative transaction based on wealth utility [53], etc.

Based on the above studies, it can be concluded that IDQ policy is a development of PES by marketized way. However, there are few studies on its pricing mechanism in the primary market or they do not consider the importance of government incentives. Therefore, establishing pricing methods for governments in the primary market is our important goal. Based on opportunity cost theory, this paper designs two models and examines the government price model with a case study.

\section{Theoretical Background and Model}

\subsection{Theoretical Background}

Opportunity cost theory serves as our theoretical base. Put forward by Friedirich von Wieser in Natural Value and developed by Samuelson and Coase, it has been a mature theory widely employed in many fields. The crucial point of opportunity cost theory demonstrates that one economic activity is at the expense of another sub-optimum activity [54], covering explicit cost and implicit cost at the same time. Given that costs and benefits play a decisive role in decision making, it is reasonable to compensate for governments' opportunity loss to inspire them to engage in environment protection. The other reason is the differences in opportunity loss between companies, which relates to production efficiency and creates the possibility of IDQ transaction. That is, the output by discharging one unit of wastewater varies from producer to producer. As a result, their opportunity costs (losses) of emission reduction are different as well. Enterprises with high production efficiency (usually in the downriver) earn more profits from one unit of wastewater and are willing to buy IDQ from those with low production efficiency (usually in the upriver).

The method of opportunity cost has simple to complex constructions: (1) Typical Area Method selects the most typical area under emission reduction policy to calculate the average opportunity cost as the price of IDQ in the whole area; (2) Batch Area Method uses the price of IDQ sampling from some areas under emission reduction policy to calculate the weighted mean and whose accuracy increases with the number of sample areas; and (3) Overall Area Method regards the weighted mean of opportunity cost of every area as the price of IDQ. This paper chooses the first method to examine our first model and to test its effects on emission reduction and its inspiration and compensation to governments.

The assumptions are: two markets and two market subjects; the primary market is issue market, where governments play the parts of price makers and are the main beneficiaries; the secondary is transaction market, where enterprises are allowed to buy or sell quotas; the governments should pay attention to their normal operation and their social responsibility for local residents, which indicates opportunity cost must cover not only fiscal income but resident's income; and the enterprises consider all their feasible strategies to maximize profits. 


\subsection{Method}

\subsubsection{Government Price Model}

According to assumptions above, we begin with the establishment of government model, aiming to give governments incentives to implement emission reduction policy.

Under emission reduction policy, economic performance of one region is bound to be weakened if there are no technology improvements or auxiliary policies, and the negative influence can be reflected by the decline of economic indexes. However, it is important to note that the decrease of one specific economic index only explains a part of opportunity cost caused by emission reduction, which means that the decline of one index may not be caused by emission reduction totally. Thus, we define the partial opportunity cost reflected by one index as single opportunity cost and construct its quantitative model as Equation (1)

$$
O C_{i t}=Z_{i}\left(Y_{i t}-Y_{i t}^{\prime}\right)
$$

where $O C_{i t}$ indicates single opportunity cost reflected by economic index $i$ in period $t, Y_{i t}$ indicates the normal growth of index $i$ in the period $t$, and $Y_{i t}^{\prime}$ indicates the growth under emission reduction policy of index $i$ in period $t$. Considering that reasons resulting in the difference between $Y_{i t}$ and $Y_{i t}^{\prime}$ are not singular, we assume $Z_{i}$ as the coefficient representing the part caused by emission reduction and $Z_{i}$ is constant during the period and different between economic indexes. For example, the gross of industrial production of one area is affected by emission reduction policy undoubtedly, while it can also be cut down if factories transfer from that area to other areas.

Furthermore, the influence made by emission reduction policy can be systematical: not only will it affect the gross value of industrial output, for example, but it impacts on fiscal income, resident income, etc. To cover the information as much as possible, we change Equation (1) to calculate multi-opportunity cost, which is defined as Equation (2)

$$
O C_{m t}=\sum_{i=1}^{n} Z_{i}\left(Y_{i t}-Y_{i t}^{\prime}\right)
$$

where $O C_{m t}$ indicates multi-opportunity cost in period $t$, and $n$ represents the number of economic indexes concerned by the governments.

Moreover, emission reduction is a periodical target rather than a goal that can be achieved at once. In this way, participants will have enough time to adjust their production and investment strategies. Therefore, finite warrant period of IDQ is equal to the prescribed period of the policy. Thus, the model calculating the basic price of IDQ in the primary market is shown as Equation (3).

$$
P_{I D Q, P M}=\frac{T C_{P M}+\sum_{t=1}^{m} \sum_{i=1}^{n} Z_{i}\left(Y_{i t}-Y_{i t}^{\prime}\right)}{\sum_{t=1}^{m} Q_{t}}
$$

where $T C_{P M}$ is transaction cost in the primary market which covers various fees such as site use fee, publicity fee, etc.; $Q_{t}$ is the objective of emission amount allowed in the $t$ year; and $m$ is the sum of years to achieve the objective. Thus, $\sum_{t=1}^{m} Q_{t}$ is the total amount of emission reduction during this period, which also represents the total amount of quota. Totally, by Equation (3), we reflect the opportunity losses of governments in the basic price of IDQ in primary market.

\subsubsection{Enterprise Model}

Suppose the secondary market of IDQ is approaching perfect competition and the transaction cost in the secondary market is equal to zero. Although IDQ is with a definite amount regulated by government, it is abundant for all enterprises. In other words, the amount of reduction is appropriate. 
In addition, enterprises are prohibited to collude so that there is no market force controlling the transaction price in the secondary market.

First, we analyze different strategies enterprise would adopt in the secondary market when their amount of IDQ is surplus or is shortage. Revenue is a crucial factor concerned by enterprises, which can be from production and selling IDQ. To unify measurement units for the better comparison, the revenue from one more unit of output is calculated by $p \times q_{0}$, where $p$ is the unit price of product and $q_{0}$ is the average product of wastewater. That is, for the first strategy, $p \times q_{0}$ indicates the average revenue from one more unit of emission. For the secondary strategy, as a price taker, the revenue is from enterprises selling one quota at the market price $P_{I D Q, S M}$.

In addition to revenue, cost is also a crucial factor affecting decisions. We have assumed the transaction costs here is zero so that the cost of buying IDQ is also equal to its market price $P_{I D Q, S M}$. This assumption seems reasonable as the transaction price is relatively small if the market system become mature. In addition, this assumption has little impact on our objective. Now, let us consider conditions of expanding production. First, the supervision system on emission is so strict that, if any enterprise is found to violate the regulation, they have to pay a price $f$ for every unit of exceeding emission. In this strategy, the fine $f$ is the expense for one more unit of exceeding emission. Secondly, enterprises can also introduce advanced technology or purchase new equipment before they run out of their IDQ, through which the emission of unit output can be reduced and the output increases. In this strategy, we should also calculate the unit cost of emission reduction $C_{T \& E}$, and the details are shown in Equation (4). Thirdly, an enterprise is allowed to buy IDQ in the secondary market (transaction market) at the unit price of $P_{I D Q, S M}$. Finally, Equation (5) summarizes the three kinds of costs above and for enterprises the final strategy is to minimize its cost.

$$
\begin{gathered}
C_{T \& E}=\frac{\sum_{j=1}^{J}\left(C_{j}-N S_{j}\right)}{\left(q_{\text {new }}-q_{\text {old }}\right)} \times q_{0} \\
C_{\min }=\min \left\{f, C_{T \& E}, P_{I D Q, S M}\right\}
\end{gathered}
$$

In Equation (4), $\left(C_{j}-N S_{j}\right)$ represents the total expenditure $C_{j}$ for new technology and equipment $j$ minus its net salvage value $N S_{j}$ (the net salvage of intangible assets is zero), $q_{\text {new }}$ indicates the total output with new technology and equipment throughout their life cycle and under a certain emission amount, $q_{\text {old }}$ indicates the total output with old ones throughout the same life cycle and under same emission limitation, and $q_{0}$ is the average product of wastewater. Thus, $\frac{\sum_{j=1}^{J}\left(C_{j}-N S_{j}\right)}{\left(q_{\text {new }}-q_{\text {old }}\right)}$ is the average cost of increased output coming from new equipment and technologies, where the industrial discharge and period are the same. $\frac{\sum_{j=1}^{J}\left(C_{j}-N S_{j}\right)}{\left(q_{\text {new }}-q_{\text {old }}\right)} q_{0}$ means the cost to reduce one unit of wastewater by the strategy of introducing new technology and equipment.

Thus, enterprises will make comprehensive and repeated comparisons of those strategies. Here, we show four alternatives based on cost-benefit analysis: (1) being a IDQ seller rather than producing more because expanding production seems not profitable, if $P_{I D Q, S M} \geq p \times q_{0}-$ $\min \left\{f, C_{T \& E}, P_{I D Q, S M}\right\}$ and there is no difference between these two strategies when the equality holds; (2) buying more quotas, if $C_{\min }=P_{I D Q, S M}$ and the prerequisite condition $P_{I D Q, S M}<$ $p \times q_{0}-\min \left\{f, C_{T \& E}, P_{I D Q, S M}\right\}$ holds; (3) introducing new technology or equipment, if $C_{\min }=C_{T \& E}$ and the prerequisite condition in Strategy 3 is also satisfied; and (4) paying a fine if $f$ is the smallest and the prerequisite condition holds. For example, if the price of one industrial discharge quota is lower than the benefits it brings and purchasing IDQ seems more profitable than introducing advanced technology, enterprises will buy more IDQ from the secondary market. 


\section{Study Area}

Pearl River is one of the grand rivers in China, spanning from the southeast to the west with a full length of $2320 \mathrm{~km}$ and full drop of $2130 \mathrm{~m}$. Its area ranks third and amount ranks second. Originated from Maxiong Mountain, the upper stream flows through the east of Yunnan and the south of Guizhou, with the length of $914 \mathrm{~km}$ and catchments area of $5.49 \times 10^{4}$ square kilometers; the middle stream clusters in Guangxi, whose catchment area reaches $2.24 \times 10^{5}$ square kilometers and water resources account for $85.5 \%$ of the total; and the down stream of Pearl River is known as Pearl River Delta, which is mainly located in Guangdong Province. With advantages of abundant water resources, economy booms in Pearl River basin.

However, economic growth also caused pollution, threatening water resources, such as acid rain, heavy metal emission, organic contamination, etc. [55]. Since the 1980s, high-energy and high-emission industries, such as electroplating factories, plastics plants, papermaking factories and hardware factories, have done great damage to the water quality of Pearl River. These factories are capital-intensive industries, whose productivity promotions are mainly through updating equipment and technologies; however, they also lack active motivation to do so. One report by Environmental Protection of Guangdong Province in 2017 showed that there were 938 factories marked for special supervision because of their serious wastewater emission. In detail, the faulty fuel combustion technologies of factories have resulted in water pollution indirectly that the frequency of acid rain in Guangdong Province has reached $26.5 \%$ in 2016 and the mean value of $\mathrm{pH}$ is 5.31. Moreover, various pollutants severely affected water quality that the quantity of sewage discharged reached 8.9 billion ton in 2016 in Guangdong Province and industrial wastewater occupied $47.3 \%$ of the total. Table 1 shows the changes of water quality grades of Pear River in recent years, where Grade I to Grade Worse Than $\mathrm{V}$ represent five indexes evaluating the level of water. Water reaching the standard of I type can be used for drinking in daily life directly after simple filtration (surface water) or simple disinfection (ground water). Nevertheless, water is prohibited from being used for daily life anymore when below Grade IV.

Table 1. Percentage of Water Quality Grades in Pearl River in 2016.

\begin{tabular}{ccccccc}
\hline Water Quality & I (\%) & II (\%) & III (\%) & IV (\%) & V (\%) & Worse Than V (\%) \\
\hline 2016 & 2.4 & 62.4 & 24.8 & 4.8 & 1.8 & 3.6 \\
2015 & 3.7 & 74.1 & 16.7 & 1.8 & 0 & 3.7 \\
2014 & 5.6 & 74.1 & 14.8 & 1.8 & 0 & 3.7 \\
\hline
\end{tabular}

Besides, Guangdong Province faces difficult tasks in solving the problem of unbalanced economic growth and income disparity. As for the whole watershed area, Table 2 reveals that Guangdong Province is a prominent economic engine for Pearl River despite its small area. It also demonstrates that the gap with the upstream and the middle stream is so wide. In other words, the economic development takes on characteristics of anti-geographical gradient, which means that economy increases gradually as the region draws near to the downstream: the upper stream (Yunnan and Guizhou) $<$ the middle stream (Guangxi) < the down stream (Guangdong). As for Guangdong itself, this phenomenon also appears. According to Figure 1, although undertaking some low-end industries from other regions, the industrial output of the upstream area in Guangdong only occupies $8.05 \%$ of the province, which is less than $1 / 10$ of the Pearl River Delta. In addition, GDP of its upstream area merely occupies $10.7 \%$ of the total, which is $1 / 8$ of the Pearl River Delta, and non-agricultural added value only occupies $8.6 \%$ of the total, which is $1 / 10.55$ of the Pearl River Delta. Considering that GDP and non-agricultural industries added value represent the quality and scale of economic performance, it seems that the upstream has not benefited from industrial diffusion and regional radiation power from the downstream yet. These problems also create an economic domino effect that the local fiscal 
occupies $4.1 \%$ of the whole province, which is less than $1 / 16$ of the Pearl River Delta, and export value occupies $2.09 \%$ of the whole province, less than $1 / 45$ of the Pearl River Delta.

Table 2. Economic indexes of main provinces in Pearl River Basin in 2016.

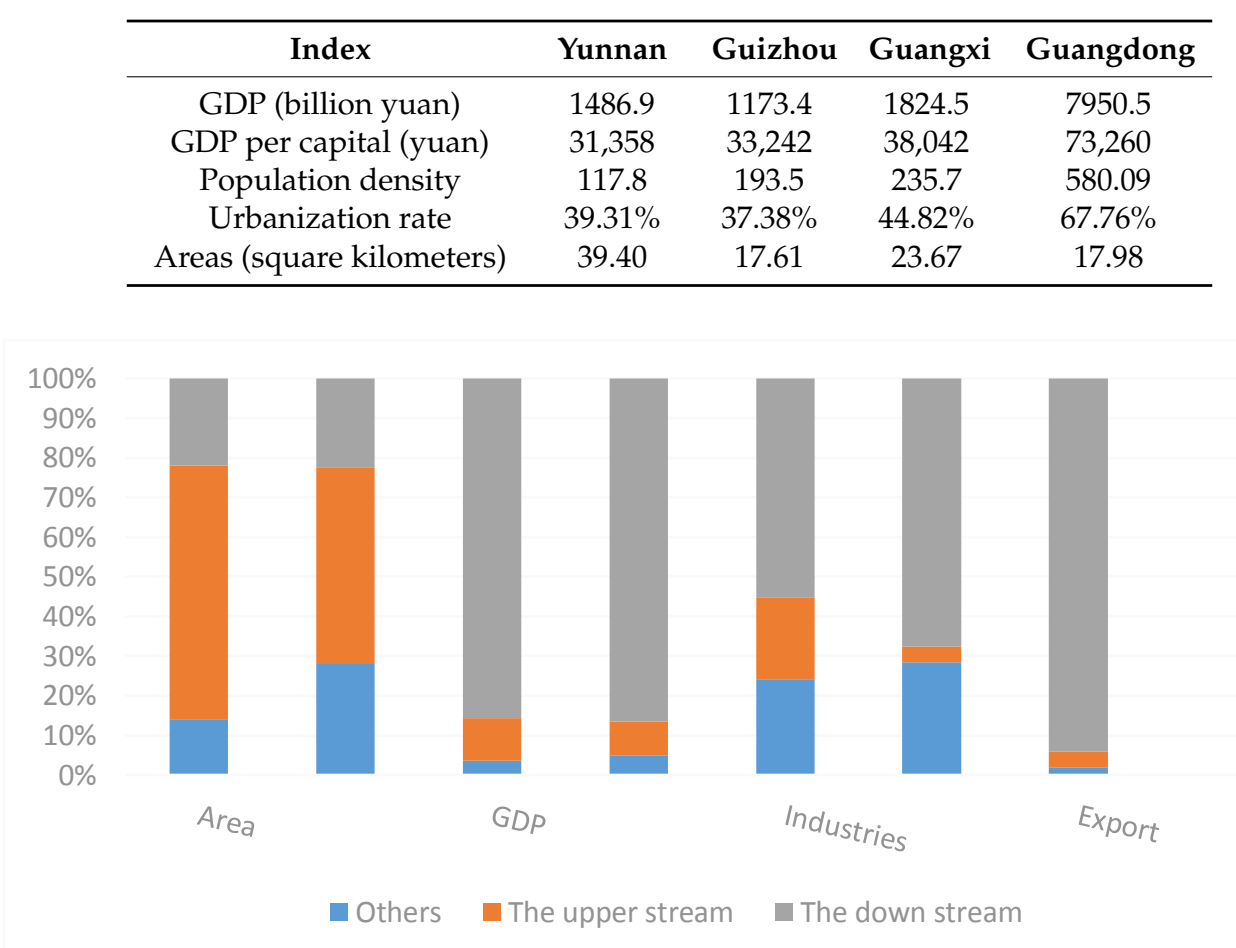

Figure 1. Major economic indexes of Pearl River in Guangdong Province.

In summary, governments in the upper stream are eager to establish more industries to keep local business vitality and increase their fiscal income because industrial sectors are the most important impetus for economic growth. However, these low-end industries are the main producers of sewage, accounting for about $50 \%$ of the total sewage in Guangdong Province and making the water quality worse and worse.

This study mainly investigates Fogang county (Figure 2): (a) which is located in the upstream in Guangdong Province and where ecosystem is vulnerable to industrial pollution; (b) which had an economic boom thanks to undertaking the transfer of low-end industry from the downstream but it is a rough manner; (c) which is to be divided into industrial limited areas for its ecological responsibility but governments are reluctant to do it; and (d) whose governments need more momentum in the economy because its scale and quality still fall behind (reflected by its relatively low income per capita).

The data are from China Provincial Statistical Yearbook, Guangdong Statistical Yearbook and Fogang Statistical Yearbook, spanning from 1980 to 2015, which are collected and revised yearly by Statistics Department. 


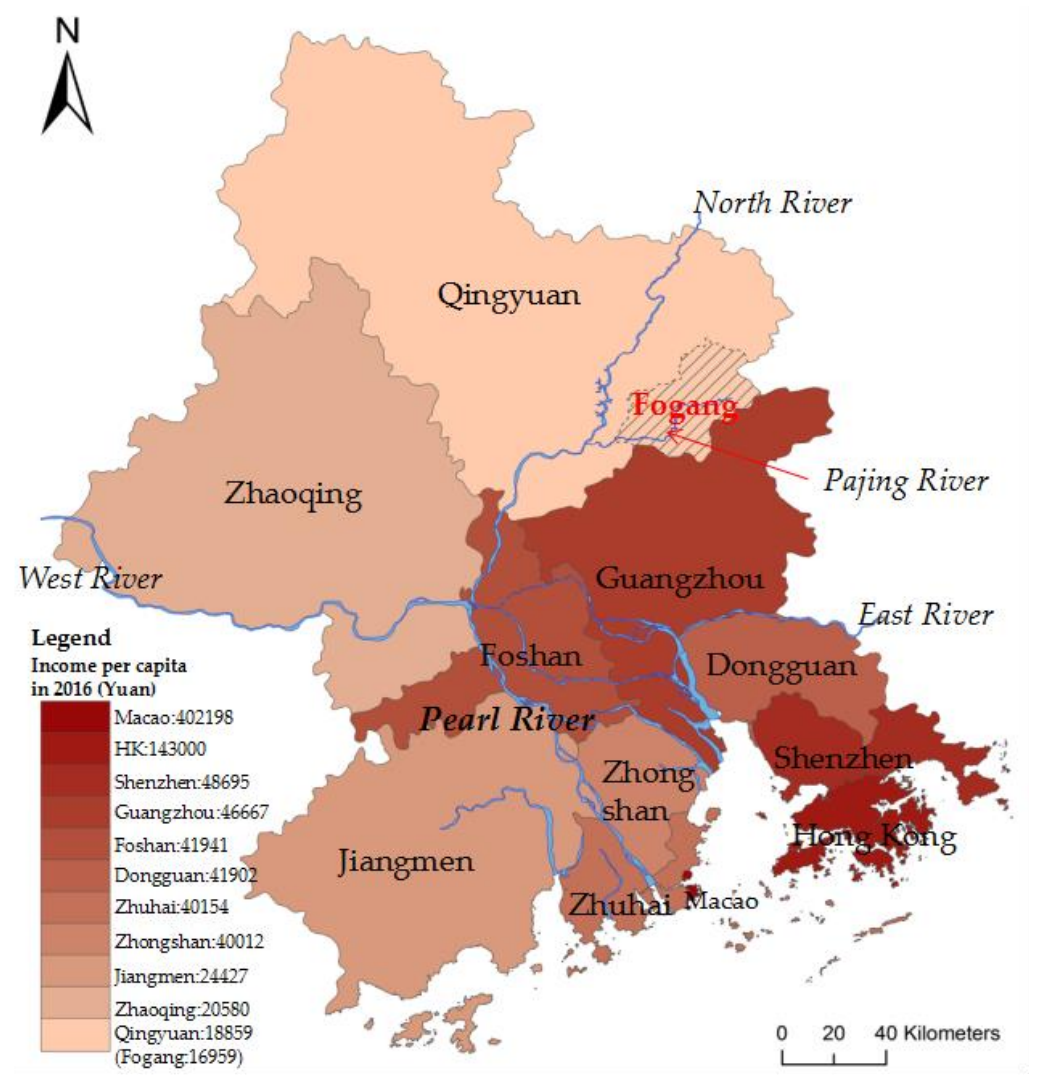

Figure 2. The location of Fogang and the distribution of income per capita in 2016.

\section{Case Study}

Using the model established in Section 3 and the data described in Section 4, this section presents our method for handling the data and the tests of our model effectiveness. First, we construct the parameter system concerning the two markets. The choices of parameters depend on different demands. Thereafter, we select an appropriate method to handle these indexes and data so that the test results are more effective.

Scenario analysis method is another method we use in this paper, given that the effect we focus on is in the near future and it is relatively difficult to access data directly. Scenario analysis is usually regarded as one of the optimal approaches to deal with uncertain risks [56], particularly for water management policies [57]. Huss [58] pointed that when a method is based on three essential principles-intuitive logic, trend-impact analysis and cross-impact analysis-various there are various methods for constructing viable scenarios. Safavi et al. [59] employed scenario analysis to his study on Zayandeh-rud basin and proved that current water management policies influenced the whole basin system.

\subsection{Basic Parameters}

Two types of parameters are shown in Table 3. This paper assumes governments are concerned about normal operation and great reputation. Measuring cost and benefit are the most important rule for maximizing profits for enterprises.

Concretely, for local governments, those in the upper stream are bound to bear huge opportunity costs when controlling wastewater, which contains the loss of fiscal income and the loss of employment. For better measurement, we replace the employment with residents' income. In this paper, our objective is to improve their initiatives in the implementation of emission reduction policy by compensating their opportunity cost. In China, for example, there are two key points supporting our indicator systems: 
(a) performance evaluation of local government is based on GDP growth and revenue resubmitted to the central government [60-62]; and (b) there is a strong correlation between local fiscal income and economic growth $[63,64]$. For example, Maskin et al. [65] made an empirical conclusion that the provincial economic performance had a positive influence on provincial representations in the Party Central Committee. Moreover, some evidence shows that the promotion and dismissal of local top leaders by central government are correlated with the local economic growth and fiscal income [61]. These two points indicate that the policy choices of local government are actually influenced by the fiscal income to a great extent.

Table 3. The industrial discharge quota (IDQ) pricing indicators.

\begin{tabular}{cccc}
\hline Markets & Transaction Subjects & Beneficiaries & Indicators \\
\hline Primary market & $\begin{array}{c}\text { Governments and } \\
\text { enterprises }\end{array}$ & Governments & $\begin{array}{c}\text { Fiscal income } \mathrm{A}_{1} \\
\text { Resident's income } \mathrm{A}_{2}\end{array}$ \\
$\begin{array}{c}\text { Secondary } \\
\text { market }\end{array}$ & $\begin{array}{c}\text { Enterprises and } \\
\text { qualified investors }\end{array}$ & Enterprises $\mathrm{A}_{3}$ \\
\hline
\end{tabular}

For enterprises, four strategies have been described in the Section 3. Here, $A_{4}$ to $A_{7}$ are all based on the unit of per emission of wastewater. That is, revenue $A_{4}$ is equal to $p \times q_{0}, A_{5}$ and $A_{6}$ are the additional costs to produce $q_{0}$ units when enterprises introduce new terminologies and equipment, and $A_{7}$ represents the fine for per unit of extra emission.

\subsection{OLS and Scenario Prediction by Exponential Smoothing Method}

Exponential smoothing method was first put forward by Brown and detailed information about its development was summarized by Gardner [66,67]. It is a prominent technique to extrapolate past data to future trends and is usually used for the prediction of short- and medium-term economic trend, production budget, etc. $[68,69]$. The strategy of this method emphasizes the effect of recent data on forecasting results by giving them a greater weight and giving the data in previous years a smaller weight. Moreover, the single exponential smoothing is applicable to the time series without an apparent trend, second exponential smoothing method is applicable to the time series with a linear trend, and three-order exponential smoothing smooths the results of second-exponential smoothing method again. In this paper, we predict normal scenario (no emission reduction) by exponential smoothing method.

For another scenario - emission reduction scenario-governments set a concrete goal of emission reduction. This article assumes that Fogang aimed to accomplish $20 \%$ emission reduction in 2020, which means the amount of emission in 2020 is around $80 \%$ of the emission in 2016 in normal scenario. Considering the goal cannot be realized at once, we assume that Fogang will reduce emission at the rate of $4.3 \%$ per year during 2016 to 2020 . Firstly, we establish a linear model of industrial output and wastewater emission and our regression also shows the relations between wastewater and other variables are not so significant. In fact, if all other factors are constant, the decline of emission will have a negative impact on industrial output directly. Then, linear regression models are established to calculate values of those economic indexes when industrial output decline. The correlations of these models are very high, and the results are shown in Table 4. 
Table 4. Estimated results of OLS.

\begin{tabular}{cccccc}
\hline Dependent Variable & Variables & Coefficient & Standard Error & $t$-Value & $p$-Value \\
\hline \multirow{2}{*}{ Gross industrial output } & Intercept & -7676.218 & 1243.607 & -6.173 & 0.000 \\
& Wastewater emission & 27.681 & 2.162 & 12.806 & 0.000 \\
\hline \multirow{2}{*}{ GDP } & Intercept & 109.511 & 128.792 & 0.850 & 0.400 \\
& Gross industrial output & 0.608 & 0.013 & 45.108 & 0.000 \\
\hline \multirow{2}{*}{ Investment in fixed assets } & Intercept & 267.521 & 112.922 & 2.369 & 0.023 \\
& Gross industrial output & 0.200 & 0.012 & 16.963 & 0.000 \\
\hline \multirow{2}{*}{ Wholesale and retail trade } & Intercept & 132.103 & 53.850 & 2.453 & 0.019 \\
& Gross industrial output & 0.166 & 0.006 & 29.557 & 0.000 \\
\hline
\end{tabular}

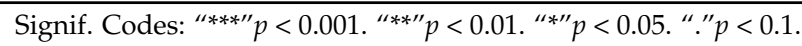

Using these linear models and exponential smoothing method, the results of the two scenario predictions are obtained (See Table 5). These results are essential for our final calculation.

Table 5. The predictive value of economic indexes in Fogang during the 13th five-year plan.

\begin{tabular}{cccccc}
\hline Time & $\begin{array}{c}\text { Investment in } \\
\text { Fixed Assets } \\
\text { (Billion Yuan) }\end{array}$ & $\begin{array}{c}\text { GDP (Billion } \\
\text { Yuan) }\end{array}$ & $\begin{array}{c}\text { Gross Industrial } \\
\text { Output Value } \\
\text { (Billion Yuan) }\end{array}$ & $\begin{array}{c}\text { The Wholesale } \\
\text { and Retail Trade } \\
\text { (Billion Yuan) }\end{array}$ & $\begin{array}{c}\text { Industrial Wastewater } \\
\text { Emissions (Ten } \\
\text { Thousand Ton) }\end{array}$ \\
\hline 2016 & 3522.75 & $11,434.02$ & $19,453.13$ & 3162.59 & 824.10 \\
2017 & 3685.945 & $12,398.41$ & $20,046.47$ & 3208.84 & 829.50 \\
2018 & 3805.547 & $13,365.03$ & $20,657.94$ & 3255.76 & 840.40 \\
2019 & 3925.15 & $14,331.65$ & $21,288.06$ & 3303.37 & 862.50 \\
2020 & 4044.753 & $15,298.27$ & $21,937.41$ & 3351.67 & 788.66 \\
& & \multicolumn{20}{c}{ Emission reduction $\mathbf{( 4 . 3 \%}$ per year) } & 754.75 \\
\hline 2016 & 3098.46 & 8715.62 & $14,154.72$ & 2481.79 & 722.30 \\
2017 & 2910.72 & 8144.87 & $13,215.99$ & 2325.96 & 691.24 \\
2018 & 2731.04 & 7598.66 & $12,317.62$ & 2176.83 & 661.51 \\
2019 & 2559.10 & 7075.94 & $11,457.88$ & 2034.11 & 1897.53 \\
\hline
\end{tabular}

\subsection{Fiscal Income $\left(A_{1}\right)$}

Here, we are going handle our first parameter-the loss of fiscal income caused by emission reduction. Because the influence factor of fiscal income is complicated, we consider it based on its sources. In China, local governments rely on taxes and land sales to fund their operations. Thus, we select GDP, the gross industrial output value, and the wholesale and retail trade and investment in fixed assets to reflect the opportunity cost information, all of which can reflect the tax loss and the last of which can reflect the income loss from land sales. However, first, it is necessary to deal with these indexes and data.

By using SPSS for multiple linear regression analysis, the results show the model is significantly well fit, where the $R^{2}=0.996$ and the adjusted $R^{2}=0.994$. That is, these four factors match the local fiscal income to a high degree. However, the results also show that the value of $t$-statistic of every independent variable is not significant and that the $\mathrm{P}$ value is relatively high, indicating that multicollinearity problem occurs among these selected factors. Furthermore, by KMO test and Bartlett ball type test, whose results are shown in Table 6, the KMO value is high, 0.759 , illustrating that the partial correlation coefficients between variables are significant; and the value of Bartlett ball type test is equal to 0.000 , proving the inter-dependency between variables. Hence, it is suitable to adopt factor analysis method to deal with the data. 
Table 6. The results of KMO and Bartlett test.

\begin{tabular}{ccc}
\hline Kaiser-Meyer-Olkin Measure of Sampling Adequacy & $\mathbf{0 . 7 5 9}$ \\
\hline & chi-squared approximation & 353.699 \\
Bartlett's test & df & 6 \\
& Sig. & 0.000 \\
\hline
\end{tabular}

By using principal component analysis, eigenvalues and variance contribution rates of every principal component are show in Table 7. It can be found that the variance contribution rates of first two principal components add up to $99.605 \%$, which are $96.572 \%$ and $3.670 \%$, respectively, and whose eigenvalues are 3.863 and 0.121 . That is, the first two principal components have contained abundant information we need and, more importantly, they do not overlap each other. Additionally, through further analysis on Rotated Component Matrix (results are omitted here for reasons of brevity), obtained by orthogonal rotation method with Kaiser standardization, we find the first principal component mainly consists of the information of GDP, the gross industrial output value, the wholesale and retail trade while the second principal component reflects information concerning investment in fixed assets. Eventually, it can get Component Score Coefficient Matrix (Table 8).

Table 7. Principal component eigenvalues and variance contribution rates.

\begin{tabular}{cccc}
\hline Principal Component & Eigenvalue & Contribution Rates (\%) & Cumulative Contribution Rate (\%) \\
\hline$F_{1}$ & 3.863 & 96.572 & 96.572 \\
$F_{2}$ & 0.121 & 3.033 & 99.605 \\
\hline
\end{tabular}

Table 8. Component Score Coefficient Matrix.

\begin{tabular}{ccc}
\hline Variable & Component $\mathbf{F}_{\mathbf{1}}$ & Component $\mathbf{F}_{\mathbf{2}}$ \\
\hline Investment in fixed assets & -1.299 & 2.073 \\
GDP & 0.876 & -0.530 \\
Gross industrial output value & 0.042 & -0.207 \\
The wholesale and retail trade & 1.109 & -0.613 \\
\hline
\end{tabular}

Next, according to the results of principal component analysis, we write Equations (6) and (7) as follows:

$$
\begin{gathered}
F_{1 t}=-1.299 X_{1 t}+0.876 X_{2 t}+0.042 X_{3 t}+1.109 X_{4 t} \\
F_{2 t}=2.073 X_{1 t}-0.530 X_{2 t}-0.207 X_{3 t}-0.613 X_{4 t}
\end{gathered}
$$

where $X_{1 t}, X_{2 t}, X_{3 t}, X_{4 t}$ correspond to the four independent variables: $X_{1 t}$ is investment in fixed assets; $X_{2 t}$ is GDP; $X_{3 t}$ is the gross industrial output value; and $X_{4 t}$ is the wholesale and retail trade. $F_{1 t}$ represents the first principal component and $F_{2 t}$ represents the second principal component.

Then, with regression analysis, a fiscal income model is established based on historical data. $A_{1 t}$ represents the fiscal income in the period $t, F_{1 t}$ represents the first principal component mainly covering $X_{2}, X_{3}$ and $X_{4}$, and $F_{2 t}$ mainly reflects information of $X_{1 t}$. The goodness of fit test shows a significant result, where $R^{2}=0.978$ and adjusted $R^{2}=0.976$.

$$
A_{1 t}=0.156 F_{1 t}+0.084 F_{2 t}-47.185
$$

\subsection{Residents' Income $\left(A_{2}\right)$}

To measure the opportunity loss of local resident' income, we calculate residents' income by employment multiplied by average wage. We find a strong connection between employment and industrial output in that low-end industries depend much on labor. 
The first step is to select variables which are correlated with employment strongly. Logically, if there are no technology improvements and other conditions are unchangeable, the increase of industrial output reflects the growth of total labor income because enterprises input more in labor resources. However, when consumption increases, the income will go down. After our repeated attempts, in this paper, we choose the relations of employment, industrial output and the wholesale and retail trade.

By our analysis, we handle all evaluation index data by utilizing exponential technique first. Table 9 shows estimated results of OLS. As can be seen, the employment is significantly associated with industrial output and the wholesale and retail trade, the former of which affects residents' income negatively and the latter of which affects employment positively. Moreover, the results, which are ignored in Table 8 , show the $R^{2}$ of this model is 0.8737 and adjusted $R^{2}$ is 0.866 . Finally, we build resident's income model as Equation (9):

$$
A_{2 t}=\exp \left\{\left[-0.006\left(\ln \left(X_{3 t}\right)\right)^{2}+0.014\left(\ln \left(X_{4 t}\right)\right)^{2}+11.6\right]\right\} W_{s}
$$

where $W_{s}$ indicates the social average wages and we discover that the social average $W_{s}$ in Guangdong Province grows steadily at the rate of around $8.7 \%$ per year.

Table 9. Summary of estimation results of the OLS.

\begin{tabular}{|c|c|c|c|c|}
\hline Variable & Coefficient & Standard Error & $t$-Value & $p$-Value \\
\hline Intercept & 11.600887 & 0.015797 & 743.357 & $<2 \times 10^{-16 * * *}$ \\
\hline$\left(\operatorname{Ln}\left(X_{3 t}\right)\right)^{2}$ & -0.006138 & 0.001129 & -5.439 & $5.05 \times 10^{-6 * * *}$ \\
\hline$\left(\operatorname{Ln}\left(X_{4 t}\right)\right)^{2}$ & 0.014142 & 0.001885 & 7.504 & $1.25 \times 10^{-8 * * *}$ \\
\hline
\end{tabular}

\subsection{The Basic Price of Industrial Discharge Quota}

Thus far, analysis has been conducted on the two crucial parameters that we select. Thereafter, combining with the scenario prediction, it can get concrete value of opportunity cost from these two aspects-fiscal income and residents' income.

By calculation, the scenario analysis, which is shown in Table 4 , has revealed that $20 \%$ emission reduction policy can contribute greatly to emission reduction in Fogang during the 13th Five-year plan. The total amount could reach about 5.89 million ton. The rest of emission sums up to 36.18 million ton, according to which equal amount of IDQ can be created. That is, the governments of Fogang will issue 36.18 million industrial discharge quotas during the period of 13th five-year plan.

Finally, using Equations (6)-(9) to evaluate the opportunity cost, it can be found that single emission reduction policy may cause great loss to fiscal income, which is about 2696 million Yuan during the five years, cut 6062 jobs approximately and reduce residents' income by around 788 million Yuan. Here, the social average wage $W_{s}$ is $29 \mathrm{k} 752$ Yuan in 2016 according to Statistical Yearbook of Guangdong Province and is assumed to increase at the rate of $8.7 \%$ per year. In addition, the coefficient of $Z_{1}$ is 0.055 , which means one unit increase in industrial output can lead to $5.5 \%$ increase in the opportunity cost of local fiscal income. The coefficient of $Z_{2}$ is 0.401 , which means one unit increase in industrial output will increase the opportunity cost of local residents' income by $41 \%$. Thus, the basic price of IDQ can be calculated as following.

$$
P_{I D Q, F M}=\frac{T S+\sum_{t=1}^{5} \sum_{i=1}^{2} Z_{i}\left(Y_{i t}-Y_{i t}^{\prime}\right)}{\sum_{t=1}^{5} Q_{t}}=\frac{26.96 \times 0.055+7.88 \times 0.41}{0.361846}+C_{0}=13.02+C_{0}
$$


where $C_{0}$ is equal to $\frac{T S}{\sum_{t=1}^{5} Q_{t}}$ and indicates the transaction cost covered by every quota.

\section{Discussion}

Thus far, calculation of the basic price of IDQ has been conducted in the primary market by adopting OLS model, exponential smoothing method and our defined government price model. In this section, verification is carried out by comparing the situation under single emission reduction policy to the situation with an auxiliary policy-IDQ policy. We also make some policy recommendations combining with the enterprise model. Prior to this process, this article makes another scenario prediction in the same way as limitation scenario to reinforce the credibility of our research results, whose goal is achieving $40 \%$ emission reduction in the 13th five-plan period and which is named as prohibition scenario.

Figures 3-7 show that single emission reduction policy does great damage to normal performance of local economy. Firstly, in Figures 5 and 6, the wholesale and retail trade and gross industrial output value are the most affected by reduction policy. Combined with Table 5 and prohibition scenario, the results reflect that they would drop by $43.4 \%$ and $51.5 \%$ in limitation scenario, respectively, and $66.3 \%$ and $72.6 \%$ in prohibition scenario, respectively, during the period. The reason for this sharp decline may be that the policy makes direct impacts on industrial production because enterprises produce less if there is no technological upgrading and innovation. This would undoubtedly attack the passion of local enterprises for expanding production as well as reduce investments. Thus, Figure 3 indicates that investments on fixed assets in Fogang will be reduced by $40.7 \%$ and $63.62 \%$ in the two scenarios, respectively. Taken together, the decline of GDP in Figure 4 concludes that local economy is highly possible to be stagnant or even go backwards and people's welfare will pay a great price under single emission reduction policy. However, unexpectedly, the results in the case study about employment indicates that it may not fall as seriously as other economic indexes. Perhaps, it is because local people accept the decreasing wages or they change ways to earn their living.

Fortunately, our government model presents the possibility of IDQ policy to deal with this problem, and water resource protection will become more flexible and smoother in this way. According to our results, in limitation scenario, with $20 \%$ emission reduction, the total amount of industrial discharge reduced in the five years is 5.894 million tons and governments can obtain 471 million Yuan directly by issuing quotas in primary market, in addition benefits from taxes and other indirect income. These are remarkable achievements made by IDQ policy and our models, which conquer the dilemma of fiscal income and water resources to a great extent. For more advantages, in our model, the basic price of IDQ is in a reasonable range for enterprises that the cost is small enough that it may not make big influence on the total output, especially for those big enterprises. It also correlates with the IDQ distribution system. Nowadays, the free allocation mechanism is still the major approach and the amount allocated in this way still accounts for a large proportion. Thus, they are really high quality assets for enterprises as they are tradable. The auction mechanism, which has been proven to have more advantages, and our model are aimed at big enterprises mainly under current conditions. However, in the future, when the overall technical level is prompted socially, this better mechanism will become the principal one.

Finally, according to our enterprise models, some policy recommendations are also proposed. First, the prerequisites of successful implementation are strict supervision and expensive fine on excessive emission, which means that the administrative penalty $f$ should be greater than the profit $p \times q_{0}-P_{I D Q, S M}$ at least. Otherwise, not only will the objective to reduce wastewater fail, but the worst would be a collapse of the IDQ market system as the quota would be undervalued and the compensation from the downstream (enterprises with higher production efficiency) to the upstream (enterprises with lower production efficiency) would be interrupted. Secondly, the comparison between the price of IDQ in secondary market $P_{I D Q, S M}$ and the profit from production $p \times q_{0}-C_{\min }$ indicates the way to develop local economy. Because the transaction market of IDQ and product is assumed 
as competition market, the price of product $p$ and the price of IDQ $P_{I D Q, S M}$ are mainly determined by markets and enterprises will be price takers. Thus, $q_{0}$ as one of the keys should given the utmost importance. It is necessary for local government to do well in guiding the domestic and foreign enterprises to establish a good industry with comparative advantages, whose marginal product of wastewater $q_{0}$ is higher than existing industries. This also helps to accomplish the adjustment of the structure of regional industry and to promote the transformation of the regional social economy. Moreover, in this way, buying quotas and continuing production are profitable and better strategies in short term, which is helpful to construct and standardize the market. Thirdly, in the long run, technology improvement seems the best final measures, which contains two aspects: the existing technology and new technology. Governments can encourage existing industries to modify their production technologies to improve water use efficiency by giving subsidies to those enterprises, which can be reflected by the increase of $q_{0}$ and the decrease of $C_{T \& E}$. In doing so, in addition to buying quotas to solve short-term issues, enterprises would become more willing to update themselves for long-term objectives.

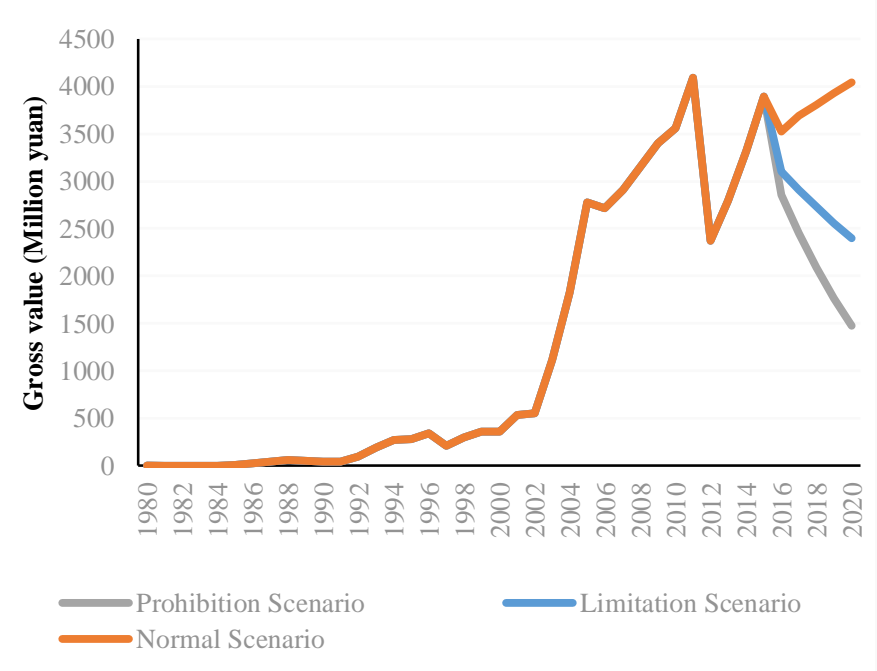

Figure 3. Investment in fixed assets.

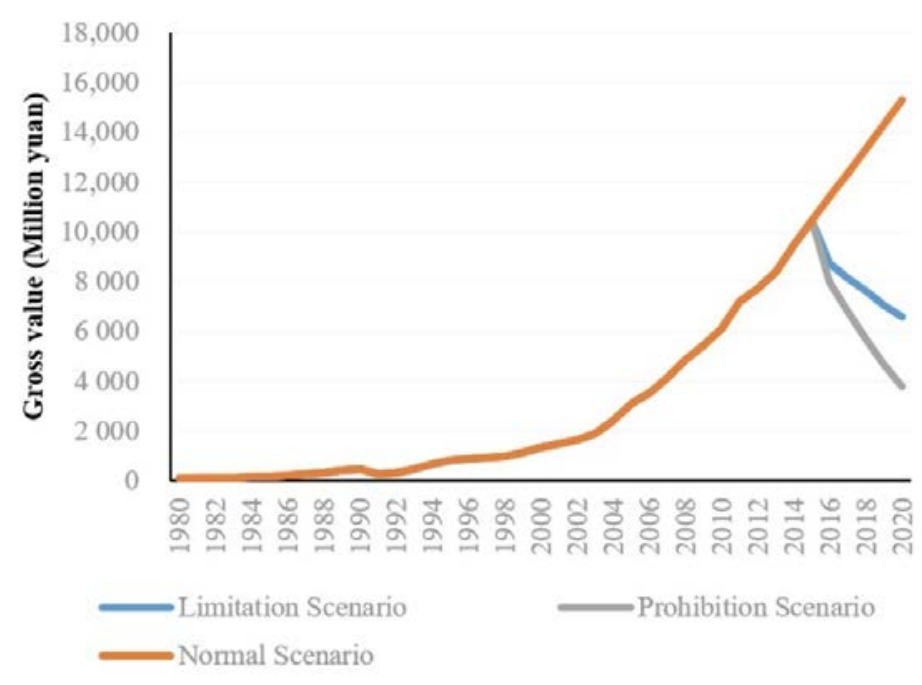

Figure 4. GDP. 


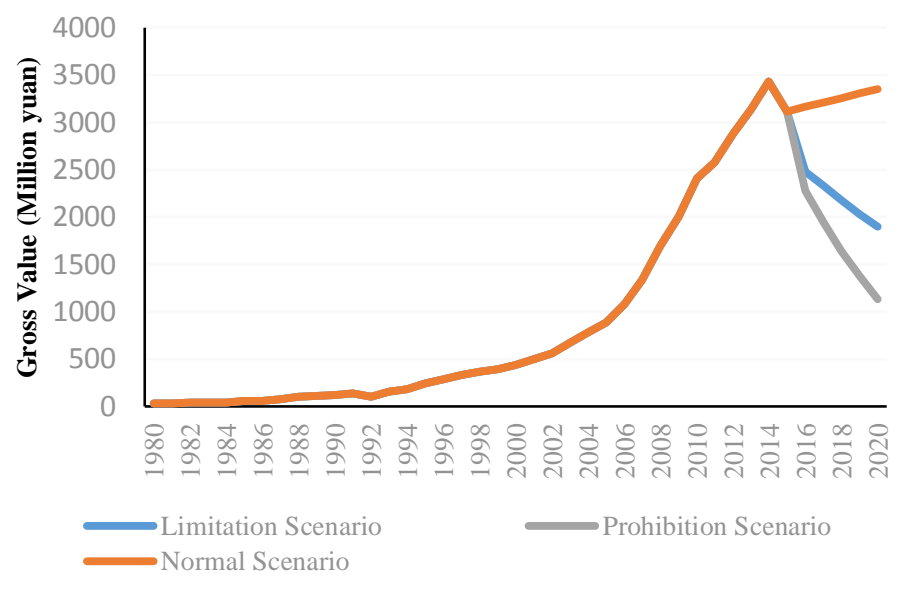

Figure 5. The wholesale and retail trade.

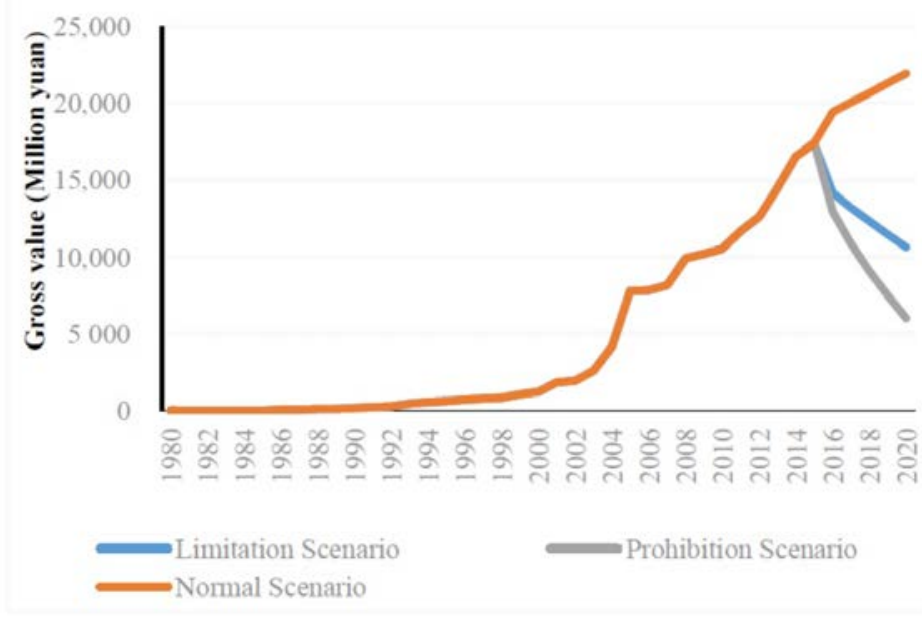

Figure 6. Gross industrial output value.

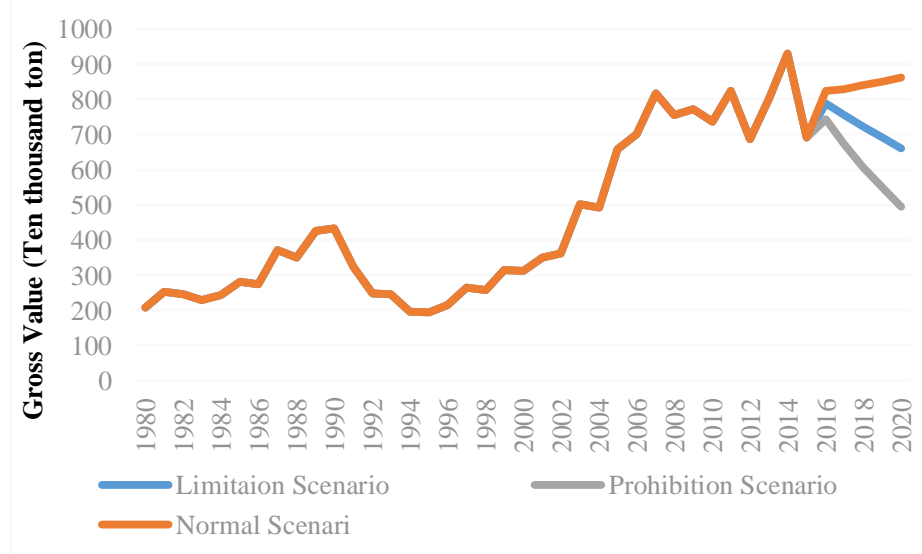

Figure 7. Industrial wastewater emissions. 


\section{Conclusions}

Although non-exhaustive, our study focuses on the problem of unbalanced regional development which is resulted from unequal ecological responsibilities and this paper proposes some important issues and a pricing scheme in primary market for local governments which aims to achieve coordinated development and water protection at the same time. We find IDQ is one of the best approach to mitigate the contradiction as it takes advantages of market power and facilitates resource dynamic assignment. Based on previous studies, our research contributes to the IDQ pricing in the primary market with the idea of giving incentives to local governments when they implement emission reduction policies with reluctance. Through our analysis, fiscal income and reputation are the crucial factors.

Specifically, from the perspective of opportunity cost theory, for local governments, our objective is to reflect the opportunity losses in the basic price of IDQ by mathematical model. Through analyzing the actual conditions, we find local governments in areas with more ecological responsibility are always reluctant to implement the policy because of their performance evaluation-fiscal income and residents' income. Thus, to compensate local governments for their opportunity loss and to inspire them, we establish the government pricing model and then we introduce these two important variables (i.e., fiscal income and residents' income) into the model to calculate the basic price of IDQ. Besides, through analyzing the enterprises' behavior, we find four strategies enterprise may take under the policy and, according to these strategies, some suggestions are made thereafter. For example, strict supervision and serious penalties are preconditions for the successful implementation. To encourage enterprises to update themselves, governments can give the special subsidies to decrease the cost.

Moreover, a case study is used to show how our model would work in a typical area and the calculation process also shows the methods by which we solve data problems. Empirical analysis illustrates that, with IDQ policy, the results of emission reduction are prominent and the motivations to governments are kept at a high level for their opportunity losses are compensated in both short and long terms. However, it has to be noted that, in this paper, the five-year compensation is paid in a lump sum under our assumption, which may increase uncertainty and risk. Thus, it is necessary for governments to make a complete and thorough plan to utilize the fortunes efficiently, such as perfecting infrastructure or setting up special funds. Another way to deal with the uncertainty in the long term, for example, is dividing the general objective into several parts, such as regarding 2016-2018 as the first stage and 2018-2020 as the second stage. Eventually, the area can change the pattern of economic development more quickly and adjust its industrial structures to accommodate the ecosystem.

There are some limitations of this study. Establishing a proper and correct pricing indicator system determines the final results and this paper focuses on fiscal income and residents' income mainly to test our model. Hence, there might be other factors ignored in this paper, which deserves further exploration. Future research can introduce more influential factors, after thoughtful consideration, into the model. This paper only verifies the feasibility of government price model due to the restriction of data, therefore future studies can take enterprises as research objects to examine how well and effectively the enterprise price model would perform and how the secondary market would work. In addition, this paper does not calculate the concrete value of transaction cost, which is just represented by formula. Although it does not greatly affect our concept model construction, it underestimates the IDQ price to a degree.

Author Contributions: T.L., J.C. and M.D. co-designed and performed research. X.D. provided the method of data analysis and modified the draft. All authors read and approved the final manuscript.

Acknowledgments: This work has been supported by National Social Science Foundation of China (Major Project No. 15ZDA054); Research Center for Industrial Development of Guangdong and its Regional Cooperation with Hong Kong, Macau and Taiwan (JD1609); and Jingwei Center for Economic Research on Guangdong, Hong Kong and Macau (JW1609).

Conflicts of Interest: The authors declare no conflicts of interest. 


\section{References}

1. Ni, J.N.; Xu, J.P.; Zhang, M.X. Constructed wetland planning-based bi-level optimization to balance the watershed ecosystem and economic development: A case study at the Chaohu Lake watershed, China. Ecol. Eng. 2016, 97, 106-121. [CrossRef]

2. Wang, M.; Webber, M.; Finlayson, B.; Barnet, J. Rural industries and water-pollution in China. J. Environ. Manag. 2008, 86, 648-659. [CrossRef] [PubMed]

3. Qiu, J. China faces up to 'terrible' state of its ecosystems. Nature 2011, 471, 19. [CrossRef] [PubMed]

4. Huang, Y.; Cai, M.T.; Zhang, J.H.; Chandmani, D.; Cai, J.L. Freshwater under Threat in Northeast Asia-Vulnerability Assessment of Freshwater Resources to Environmental Change. United Nations Environmental Programme, Nairobi. J. Urban Technol. 2008, 22, 1-15.

5. Ministry of Environmental Protection [CHN MEP]. China's Coastal Marine Environment Quality Bulletin. 2012. Available online: http://www.zhb.gov.cn/hjzl/zghjzkgb/lssj/2012nzghjzkgb/ (accessed on 22 December 2017).

6. Water Resources Group. Charting Our Water Future: Economic Frameworks to Inform Decision-Making; 2030 Water Resource Group: Melbourne, Australia, 2009.

7. Zhang, B.; Zhang, H.; Liu, B.B.; Bi, J. Policy interactions and under-performing emission trading markets in China. Environ. Sci. Technol. 2013, 47, 7077-7084. [CrossRef] [PubMed]

8. Yao, L.X.; Chang, Y.H. Shaping China's energy security: The impact of domestic reforms. Energy Policy 2015, 77, 131-139. [CrossRef]

9. Dai, M.; Liu, Y.N.; Chen, X.D. Industrial Discharge Quota (IDQ) Based on Major Functional Area and Ecological Compensation. Ecol. Econ. 2012, 7, 112-116.

10. Bennett, G.; Carroll, N.; Hamilton, K. Charting New Waters: State of Watershed Payments 2012; Forest Trends: Washington, DC, USA, 2013; Available online: http:/ /www.forest-trends.org/documents/files/doc_3308.pdf (accessed on 22 December 2017).

11. Huang, M.; Upadhyaya, S.; Jindal, R.; Kerr, J. Payments for watershed services in Asia: A review of current initiatives. J. Sustain. For. 2009, 28, 551-575. [CrossRef]

12. Brouwer, R.; Tesfaye, A.; Pauw, P. Meta-analysis of institutional-economic factors explaining the environmental performance of payments for watershed services. Environ. Conserv. 2011, 38, 380-392. [CrossRef]

13. Rosa, H.; Kandel, S.; Dim, L. Compensation for Environmental Services and Rural Communities: Lessons from the Americas. Int. For. Rev. 2004, 6, 87-94. [CrossRef]

14. Lindemann, S. Understanding Water Regime Formation-A Research Framework with Lessons from Europe. Glob. Environ. Politics 2008, 8, 117-140. [CrossRef]

15. Ministry of Finance (MOF). Table of the Transfer Payments for Key Ecological Functional Zones. Available online: http:/ /yss.mof.gov.cn/ybxzyzf/zdstgnqzyzf/201610/P020161-014584094976997.pdf (accessed on 18 February 2017). (In Chinese)

16. Liu, G.H.; Wen, Y.H.; Jin, T.T.; Hao, H.G.; Liu, S.F. Designing of watershed ecological compensation mechanism based on the key ecological function zone: a case study in the source area of Dongjiang River. Adv. Mater. Res. 2013, 807-809, 962-975. [CrossRef]

17. Fu, S.; Cao, Y.; Wan, B. Study on incorporation of eco-sensitive county into the general transfer payment-A case study of Hebei province. J. Green Sci. Technol. 2016, 2, 135-137.

18. UN-Water. Water Security \& the Global Water Agenda; UN-Water Analytical Brief; UNU-INWEH: Hamilton, ON, Canada, 2013.

19. Harret, T.W.H.; Wang, H.D.; Wang, L.H. The comprehensive evaluation method of urban sustainable development. China Popul. Resour. Environ. 1997, 7, 46-50.

20. Shaker, R.R.; Sirodoev, I.G. Assessing sustainable development across Moldova using household and property composition indicators. Habitat Int. 2016, 55, 192-204. [CrossRef]

21. Wang, Z.G.; Luo, Y.Z.; Zhang, M.H.; Xia, J. Quantitative Evaluation of Sustainable Development and Eco-Environmental Carrying Capacity in Water-Deficient Regions: A Case Study in the Haihe River Basin, China. J. Integr. Agric. 2014, 13, 195-206. [CrossRef]

22. United Nations, Sustainable Development Knowledge Platform. 2015. Available online: https:// sustainabledevelopment.un.org/topics (accessed on 20 July 2016). 
23. Wunder, S. Payments for Environmental Services: Some Nuts and Bolts; Occasional Paper No. 42; Center for International Forestry Research: Bogor, Indonesia, 2005; Volume 42, pp. 1-25.

24. Wunder, S. Revisiting the concept of payments for environmental services. Ecol. Econ. 2015, 117, $234-243$. [CrossRef]

25. Gabriela, S.; Jeff, B. Can payments for ecosystem services schemes mimic markets. Ecosyst. Serv. 2017, 23, 30-37.

26. Corbera, E. Valuing nature, paying for ecosystem services and realizing social justice: A response to Matulis (2014). Ecol. Econ. 2015, 110, 154-157. [CrossRef]

27. Van Hecken, G.; Bastiaensen, J.; Windey, C. The frontiers of the debate on payments for ecosystem services a proposal for innovative future research. Inst. Dev. Policy Manag. 2015, 5, 5-39.

28. Muradian, R.; Corbera, E.; Pascual, U.; Kosoy, N.; May, P.H. Reconciling theory and practice: An alternative conceptual framework for understanding payments for environmental services. Ecol. Econ. 2010, 69, 1202-1208. [CrossRef]

29. Gómez-Baggethun, E.; Muradian, R. In markets we trust? Setting the boundaries of market-based instruments in ecosystem services governance. Ecol. Econ. 2015, 117, 217-224. [CrossRef]

30. Dales, J.H.; Winch, D.M. Pollution, property and Prices. Can. J. Econ./Rev. Can. Econ. 1968, 2, 322.

31. Crocker, T.D. The structuring of atmospheric pollution control systems. Econ. Air Pollut. 1966, $29,288$.

32. Montgomery, W.D. Markets in licenses and efficient pollution control programs. J. Econ. Theory 1972, 5, 395-418. [CrossRef]

33. Bohm, P. Distributional implications of allowing international trade in $\mathrm{CO}_{2}$ emission quotas. World Econ. 1992, 15, 107-114. [CrossRef]

34. Fisher-Vanden, K.A.; Shukla, P.R.; Edmonds, J.A.; Kim, S.H.; Pitcher, H.M. Carbon Taxes and India. Energy Econ. 1997, 19, 289-325. [CrossRef]

35. Chan, G.; Stavins, R.N.; Stowe, R.; Sweeney, R. The $\mathrm{SO}_{2}$ Allowance Trading System and the Clean Air Act Amendments of 1990: Reflection on Twenty Years of Policy Innovation; Social Science Research Netword Electronic Journal, 2012; Volume 62, pp. 419-452. Available online: https:/ / ssrn.com/abstract=1997310 (accessed on 9 June 2018).

36. Kalaitzoglou, L.; Ibrahim, B.M. Trading patterns in the European carbon market: The role of trading intensity and OTC transactions. Q. Rev. Econ. Finance 2013, 53, 402-416. [CrossRef]

37. Kossoy, A.; Ambrosi, P. State and Trends of the Carbon Markets, 2010. The World Bank Report. Washington, DC, USA, 2010. Available online: https:/ / openknowledge.worldbank.org/handle/10986/13401 (accessed on 22 December 2017).

38. Linacre, N.; Kossoy, A.; Ambrosi, P. State and Trends of the Carbon Market 2011. The World Bank Report. Washington, DC, USA, 2011. Available online: https:/ /openknowledge.worldbank.org/handle/10986/13399 (accessed on 22 December 2017).

39. Zhou, P.; Zhang, L.; Zhou, D.Q.; Xia, W.J. Modeling economic performance of interprovincial $\mathrm{CO}_{2}$ emission reduction quota trading in China. Appl. Energy 2013, 112, 1518-1528. [CrossRef]

40. Qin, Q.; Liu, Y.; Li, X.; Li, H. A multi-criteria decision analysis model for carbon emission quota allocation in China's east coastal areas: Efficiency and equity. J. Clean. Prod. 2017, 168, 410-419. [CrossRef]

41. Hahn, R.W. Market Power and Transferable Property Rights. Q. J. Econ. 1984, 99, 753-765. [CrossRef]

42. Fan, Y.; Zhang, X.B.; Zhu, L. Estimating the macroeconomic costs of $\mathrm{CO}_{2}$ emission reduction in China based on multi-objective programming. Adv. Clim. Chang. Res. 2010, 1, 27-33. [CrossRef]

43. Goeree, J.; Holt, C.A.; Palmer, K.; Burtraw, D. An experimental study of auctions versus grandfathering to assign pollution permits. J. Eur. Econ. Assoc. 2010, 8, 514-525. [CrossRef]

44. Pizer, W. Combining price and quantity controls to mitigate global change. J. Public Econ. 2002, 85, 409-434. [CrossRef]

45. Betz, R.; Seifert, S.; Cramton, P.; Kerr, S. Auctioning greenhouse gas emissions permits in Australia. Aust. J. Agric. Resour. Econ. 2010, 54, 219-238. [CrossRef]

46. Christiansen, A.C.; Arvanitakis, A.; Tangen, K.; Hasselknippe, H. Price determinants in the EU emissions trading scheme. Clim. Policy 2005, 5, 15-30. [CrossRef]

47. Mansanet-Bataller, M.; Pardo, A.; Valor, E. $\mathrm{CO}_{2}$ prices, energy and weather. Energy J. 2007, $28,73-92$. [CrossRef] 
48. Bredin, D.; Muckley, C. An emerging equilibrium in the EU emissions trading scheme. Energy Econ. 2011, 33, 353-362. [CrossRef]

49. Johnson, S.L.; Pekelney, D.M. Economic assessment of the regional clean air incentives market: A new emissions trading program for Los Angeles. Land Econ. 1996, 72, 277-297. [CrossRef]

50. O'Neill, R.P.; Sotkiewicz, P.M.; Hobbs, B.F.; Rothkopf, M.H.; Stewart, W.R. Efficient market-clearing prices in market with non-convexities. Eur. J. Oper. Res. 2005, 164, 269-285. [CrossRef]

51. Seifert, J.; Uhrig-Homburg, M.; Wagner, M. Dynamic behavior of $\mathrm{CO}_{2}$ spot prices. J. Environ. Econ. Manag. 2008, 56, 180-194. [CrossRef]

52. Yao, E.Q.; Rao, Y.F.; Li, Z.K. Calculation of emission permits pricing based on replacement cost method-Taking COD emission in Shenyang as an example. J. Liaoning Norm. Univ. (Nat. Sci. Ed.) 2012, 35, 557-562.

53. Wu, F.P.; You, M.; Yu, Q.W. Research on emission pricing model based on wealth utility under multi-scenario. Soft Sci. 2017, 31, 108-111.

54. Von Wieser, F. Theorie der Gesellschaftlichen Wirtschaft [Theory of Social Economics]; Mohr Siebeck: Tübingen, Germany, 1914. (In German)

55. Zhang, G.L.; Bai, J.H.; Xiao, R.; Zhao, Q.; Jia, J.; Cui, B.; Liu, X. Heavy metal fractions and ecological risk assessment in sediments from urban, rural and reclamation-affected rivers of the Pearl River Estuary, China. Chemosphere 2017, 187, 278-288. [CrossRef] [PubMed]

56. Zamar, D.S.; Bhushan, G.; Sokhansanj, S.; Newlands, N.K. A quantile-based scenario analysis approach to biomass supply chain optimization under uncertainty. Comput. Chem. Eng. 2017, 97, 114-123. [CrossRef]

57. Pallottino, S.; Sechi, G.M.; Zuddas, P.A. DSS for water resources management under uncertainty by scenario analysis. Environ. Model. Softw. 2005, 20, 1031-1042. [CrossRef]

58. Huss, W.R. A move toward scenario analysis. Int. J. Forecast. 1988, 4, 377-388. [CrossRef]

59. Safavi, H.R.; Golmohammadi, M.H.; Sandoval-Solis, S. Expert knowledge based modeling for integrated water resources planning and management in the Zayandehrud River Basin. J. Hydrol. 2015, 528, 773-789. [CrossRef]

60. Blanchard, O.; Shleifer, A. Federalism with and without Political Centralization: China versus Russia 48; IMF Staff Papers; IMF: Washington, DC, USA, 2001; pp. 171-179.

61. Li, H.B.; Zhou, L.A. Political turnover and economic performance: The incentive role of personnel control in China. J. Public Econ. 2005, 89, 1743-1762. [CrossRef]

62. Xu, C.G. The fundamental institutions of China's reforms and development. J. Econ. Lit. 2011, 49, $1076-1151$. [CrossRef]

63. Weingast, B.R. Second generation fiscal federalism: The implications of fiscalincentives. J. Urban Econ. 2009, 65, 279-293. [CrossRef]

64. Rodden, J. Reviving Leviathan: Fiscal federalism and the growth of government. Int. Organ. 2003, 57, 695-729. [CrossRef]

65. Maskin, E.; Qian, Y.Y.; Xu, C.G. Incentives, information, and organizational form. Rev. Econ. Stud. 2000, 67, 359-378. [CrossRef]

66. Gardner, E.S. Exponential smoothing: the sate of the art. Int. J. Forecast. 1985, 4, 1-28. [CrossRef]

67. Gardner, E.S. Exponential smoothing: The state of the art-Part II. Int. J. Forecast. 2006, 22, $637-666$. [CrossRef]

68. Baki, B.; Maxwell, L.K.; Ralph, D.S.; Anne, B.K. Exponential smoothing model selection for forecasting. Int. J. Forecast. 2006, 22, 239-247.

69. Wu, L.F.; Liu, S.F.; Yang, Y.J. Grey double exponential smoothing model and its application on pig price forecasting in China. Appl. Soft Comput. 2016, 39, 117-123. [CrossRef]

(C) 2018 by the authors. Licensee MDPI, Basel, Switzerland. This article is an open access article distributed under the terms and conditions of the Creative Commons Attribution (CC BY) license (http:/ / creativecommons.org/licenses/by/4.0/). 